\title{
Recenzja książki „Jakość i ocena tłumaczenia” pod redakcją A. Kopczyńskiego i M. Kizeweter
}

\section{Review of Jakość $\boldsymbol{i}$ ocena thumaczenia Edited by A. Kopczyński and M. Kizeweter}

\author{
Paulina Kozanecka \\ ZAKŁAD LEGILINGWISTYKI I JĘZYKÓW SPECJALISTYCZNYCH, \\ UNIWERSYTET IM. ADAMA MICKIEWICZA \\ AL. NIEPODLEGŁOŚCI 4, 61-874 POZNAŃ \\ skorupska@amu .edu.pl
}

Książka „Jakość i ocena tłumaczenia” wydana pod redakcją Andrzeja Kopczyńskiego i Magdaleny Kizeweter przez Wydawnictwo Szkoły Wyższej Psychologii Społecznej „Academica” (Warszawa 2009) porusza kwestie związane z kryteriami oceny tłumaczenia i klasyfikacją najczęstszych błędów i dotyczy najróżniejszych rodzajów i typów przekładu - od literackiego tłumaczenia pisemnego począwszy, poprzez tłumaczenia specjalistyczne, np. prawnicze lub audiowizualne, aż po tłumaczenie konferencyjne. Pozycja ta podzielona została na trzy rozdziały: rozdział pierwszy - „Ogólne problemy oceny tłumaczenia”, w ramach którego ujęte zostało sześć artykułów; rozdział drugi - „Tłumaczenie specjalistyczne” także obejmujący sześć tekstów; oraz rozdział trzeci - „Błędy w tłumaczeniu”, do którego zaklasyfikowany został tylko jeden artykuł. Większość tekstów - bo aż dziewięć - napisanych zostało w języku polskim, cztery natomiast powstały w języku angielskim. Artykuły dotyczą zarówno kwestii teoretycznych, jak i praktycznych.

We wstępie redaktorzy zwracają uwagę na cel publikacji, jakim jest skupienie się na ocenie tłumaczenia. Wskazują, że w naukach humanistycznych znacznie częściej dokonuje się samego opisu zjawisk, niż ich oceny. Jest to faktycznie ciekawe spostrzeżenie; co więcej, treść artykułów zamieszczonych w tej publikacji zdaje się potwierdzać znaczenie prowadzenia badań także i w tym kierunku. Warto w tym momencie zwrócić uwagę na sam tytuł publikacji, który w niezwykle trafny i zarazem zwięzły sposób skupia problematykę wszystkich zawartych w nim artykułów.

Wprowadzający artykuł w rozdziale pierwszym „Ogólne problemy oceny tłumaczenia” - „Kryteria jakości i oceny tłumaczenia”, napisany został przez Andrzeja Kopczyńskiego, będącego także redaktorem publikacji. Tekst porusza w ogólnym stopniu temat zawarty w tytule książki. 
Autor rozpoczyna tekst starając się zdefiniować jakże trudne do uchwycenia pojęcie „jakości”, wskazując na dwie jego główne definicje: „stopień doskonałości” oraz „stopień zgodności z przyjętą normą”. Następnie dokonuje przeglądu kilku różnych definicji tłumaczenia - sformułowanych przez Jeana-René Ladmirala (1979), Aleksandra Luskanowa (1973), Olgierda A. Wojtasiewicza (1957) i Eugene A. Nidę (1964) oraz określa, jak w każdej $\mathrm{z}$ podanych definicji mierzona jest jakość tłumaczenia. Zdefiniowawszy przedmiot artykułu autor przechodzi do wskazania kryteriów oceny jakości tłumaczenia. Rozróżnia dwa kryteria oceny jakości tłumaczenia: kryterium treści i formy tłumaczenia oraz kryterium wierności tłumaczenia. W przypadku kryterium pierwszego zaznacza wagę problemu, jaki wiąże się z decyzją, co w tekście źródłowym winno być zachowane - czy jego forma (tłumaczenie „słowo do słowa”), czy też treść (a więc „sens do sensu”), uzależniając tę decyzję od typu tekstu (czy jest to tekst ekspresywny, informatywny, czy apelatywny). Analizując kryterium drugie autor opisuje semantyczne i komunikacyjne sposoby tłumaczenia oraz nawiązuje do pojęć ekwiwalencji, kongruencji oraz korespondencji tekstów. Wspomina także o znaczeniu celu tłumaczenia, który to problem sformułowali Vermeer i Reiss w teorii skoposu. Autor podsumowuje artykuł stwierdzając, że określenie jakości tłumaczenia w znacznym stopniu uzależnione jest od aspektów kulturowych, sytuacyjnych i językowych. Uzależnia je również od osoby oceniającej tłumaczenie, podkreślając, że może się ono różnić jeśli tłumaczenie oceniać będzie ekspert, klient/odbiorca lub klient/zleceniodawca - przy czym podkreśla, że dla tłumacza najważniejszy w tym wypadku powinien być klient. Artykuł zwięźle przedstawia więc najbardziej znaczące aspekty tłumaczenia mogące mieć znaczenie dla oceny jego jakości. Może stanowić znaczną pomoc dla dokonującego takiej oceny, wskazując, na jakie elementy przede wszystkim powinno się zwrócić uwagę.

Drugi artykuł, autorstwa Piotra Blumczyńskiego, zatytułowany został „O jakościowej przewadze przekładu nad oryginałem”. Ta przewrotna poniekąd teza uzasadniona została przez autora kilkoma szczególnymi przykładami z historii tłumaczenia, a także kilkoma współczesnymi. Po pierwsze, wskazał na podejście do tłumaczenia funkcjonujące w starożytnym Rzymie, kiedy to tłumacza uważano za „zdobywcę" i „zwycięzcę" nad tekstem i przyznawano mu pełne prawo do ingerencji w tekst źródłowy i swobodne przełożenie go na tekst będący de facto nowym, lepszym dziełem. Po drugie, przytacza przykład Wulgaty jako „doskonałego” przekładu Biblii, przez całe wieki uznawanego za ważniejszy od hebrajsko-greckiego oryginału, a nawet oficjalnie ustanowionego jako „prawdziwszy”. Idąc dalej autor przedstawia oświeceniowy stosunek do przekładu, zgodnie z którym tłumacz mógł dokonać oceny oryginału i ulepszyć go, eliminując jego ewentualne słabości; wierność miała w tym przypadku znaczenie drugorzędne. Kolejnym przytoczonym przykładem jest sytuacja, w której przekładu dokonał tłumacz „znakomitszy” od twórcy; tłumaczenie może być wówczas uznane za dzieło dużo lepsze od pierwowzoru. Ostatnią z przedstawionych jest kwestia celu tłumaczenia 
zgodnie $\mathrm{z}$ teorią skoposu. W przypadku np. tekstu informacyjnego, w którym autor dokonał licznych błędów co do treści informacji, tłumacz ma prawo dokonać odpowiednich poprawek (inaczej tekst docelowy nie będzie spełniał swojej roli) - i natenczas nie można sprzeciwić się, że przekład będzie mieć nad oryginałem przewagę. Inaczej sprawa ma się w przypadku tłumaczenia literackiego, gdzie bardzo trudno rozeznać oczywisty błąd twórcy; autor artykułu przywołuje przypadek „poprawionego” tłumaczenia Biblii na język politycznie poprawny, m.in. niwelujący wyraźną znaczniejszą rolę mężczyzn w czasach biblijnych - jednakże o takich próbach autor wypowiada się w sposób jednoznaczny krytycznie. Podsumowując artykuł stwierdza, że „jakościową przewagę przekładu nad oryginałem dopuszcza jedynie takie rozumienie istoty tłumaczenia, w którym wartość tekstu oryginalnego nie jest jego cechą immanentną, lecz pochodną treści bądź funkcji”. Tekst Piotra Blumczyńskiego porusza niewątpliwie ciekawy temat i może skłonić niejednego tłumacza do refleksji nad tym, w jakim stopniu powinno się zabiegać, aby tekst docelowy mógł - w rzeczy samej przewyższać oryginał.

Kolejny artykuł - „Functional Assessment in Literary Translation” napisany został przez Izabelę Szymańską. Autorka dokonuje oceny tłumaczenia literackiego na przykładzie utworu „Twelve Red Herrings” autorstwa J. Archer („Dwanaście fałszywych tropów” w tłumaczeniu K. Sokołowskiego i M. Wroczyńskiego). Utwór opiera się na zasadzie podawania czytelnikowi właśnie fałszywych tropów, aby pod koniec opowieści wyjawić, co tak naprawdę się wydarzyło - przy czym zaznaczyć należy, że głównym problemem jest zmylenie czytelnika co do płci jednej z postaci. Z uwagi jednak na fakt, że gramatyka języka angielski zdecydowanie ułatwia to zadanie, a języka polskiego - wręcz przeciwnie, autorka artykułu zarzuca tłumaczom gramatyczne „oszustwo”, do którego się dopuścili, starając się wprowadzić czytelnika w błąd. Dokonuje przy tym szczegółowej analizy porównawczej tekstu źródłowego i docelowego w tłumaczeniu K. Sokołowskiego i M. Wronczyńskiego, a także proponuje własne tłumaczenie, wskazując na techniki, które jej zdaniem umożliwiłyby uniknięcie „oszustwa” i „właściwe” skierowanie czytelnika na fałszywy trop. Artykuł w bardzo interesujący sposób przedstawia kwestię tłumaczenia tekstu z zachowaniem pełnionej przez ten tekst funkcji.

Autorką kolejnego artykułu, „Przepis na przypis - o przypisach na podstawie wybranych przykładów anglojęzycznej literatury pięknej w przekładzie na język polski”, jest Magdalena, będąca jednocześnie redaktorem publikacji. Autorka dokonuje rozróżnienia przypisów pod względem ich pochodzenia (od autora, redaktora lub tłumacza), a także funkcji. Wskazuje, że przypisy odautorskie stanowić mogą zarówno element fabuły, jak i komentarz do niej; przypisy redaktora pełnią głównie funkcję informacyjną, natomiast najbardziej różnorodne są przypisy tłumacza - i to na nich w głównej mierze skupia się artykuł. W artykule wyróżnione zostały przypisy tłumacza będące uwagami technicznymi, komentarzem do treści, informacją o tłumaczu innego dzieła, którego fragment został zawarty w utworze (autorka określa te przypisy mianem „praw autorskich”) i wreszcie 
przypisy wyjaśniające elementy językowe i kulturowe, zarówno wyjściowe, jak i docelowe (a także ewentualnie - języka trzeciego, jeśli takowe znalazły się w tekście źródłowym). Autorka rozważa celowość przypisów pod względem ich użyteczności, stopnia ingerencji tłumacza w odbiór tekstu docelowego, a także zwracając uwagę na kwestie czysto estetyczne. Tekst wzbogacony jest o liczne przykłady, które są doskonałą ilustracją do stawianych przez autorkę tez. Z pewnością artykuł ten może być cenną wskazówką dla tłumacza, który rozważa czy w przekładanym przez niego tekście warto zastosować przypisy, czy też nie.

Artykuł "Quality and Criteria of its Evaluation in Conference Interpreting”, napisany przez Ewę Kościałkowską-Okońską, skupia się na problemie oceny jakości tłumaczenia konferencyjnego. Pojęcie jakości w kontekście tłumaczenia konferencyjnego autorka $\mathrm{w}$ dużym stopniu utożsamia z komunikacją efektywną pod każdym względem. Jako metodę badania tej efektywności podaje kwestionariusze kierowane do uczestników konferencji. Przytaczane ankiety opracowane zostały przez Bühler (1986), Kurz (1989, 1993) i Kopczyńskiego (1994). Kwestionariusze dotykały problemów zarówno czysto językowych, jak terminologia czy gramatyka, jak i dotyczących odczuć słuchaczy, np. płynności wypowiedzi lub dykcji tłumacza, a nawet jego wyglądu. Autorka zestawia wyniki ankiet i podsumowuje je, porównując je z obserwacjami dokonanymi przez innych specjalistów - m.in. Viezzi (1996) czy Pöchhackera (2000, 2002). Wskazuje na wysoką subiektywność ocen stawianych przez uczestników konferencji, a także zwraca uwage na fakt, że od tłumacza konferencyjnego wymaga się praktycznie niemożliwego - być zarazem niedostrzegalnym i nie ingerować w tłumaczoną wypowiedź, bądź pełnić rolę mediatora, który niweluje wszelkie „wpadki” rozmówców. Artykuł podnosi istotny problem zmierzenia rzeczy tak naprawdę nie całkiem mierzalnej, jaką jest jakość tłumaczeń konferencyjnych - biorąc pod uwagę trudność w ustaleniu ostatecznych kryteriów tej jakości.

W artykule „Jakość własnego oraz cudzego tłumaczenia symultanicznego w ocenie studentów” autorka Magdalena Bartłomiejczyk porusza podobny problem, jednak podchodzi do niego z inne strony - tym razem bowiem ocena nie pochodzi od odbiorców, ale od samych tłumaczy. Celem autorki była analiza postrzegania tłumaczenia własnego i cudzego przez studentów programu tłumaczeniowego, zaobserwowanie i zanalizowanie ewentualnych różnic. Artykuł stanowi zatem opis przebiegu i przedstawienie wyników dwóch eksperymentów przeprowadzonych przez autorkę. W trakcie badań zadaniem studentów było symultaniczne tłumaczenie tekstów, a następnie odsłuchiwanie nagrań z tych tłumaczeń (własnych, jak i cudzych) oraz swobodne notowanie lub nagrywanie uwag. Wyniki autorka podzieliła względem różnych kryteriów jakości, o których jednak nie uprzedzano studentów przed przeprowadzeniem badania. Na podstawie eksperymentu autorka zaobserwowała, że oceny studentów były pod pewnymi względami zdecydowanie subiektywne, co skłoniło ją do refleksji, że samoocena niekoniecznie może stanowić dobry wskaźnik w badaniu efektów kształcenia studentów, chyba że zastosowano by 
zestandaryzowane arkusze sugerujące obszary, na których dokonujący samooceny powinni skupić swoją uwagę. Badanie Magdaleny Bartłomiejczyk może stanowić szczególną wskazówkę dla osób związanych z dydaktyką przekładu, wskazuje bowiem konkretne obszary, na jakie nauczyciel osobiście powinien zwrócić uwagę kształcąc przyszłych tłumaczy symultanicznych.

W rozdziale drugim publikacji, „Tłumaczenie specjalistyczne”, pierwszy artykuł - „Specyfika przekładu tekstów prawnych a wybory tłumacza na przykładzie angielskich tłumaczeń tekstów ustaw" napisany został przez Izabelę Jędrzejowską. Autorka opisuje problematykę tłumaczenia tekstów prawnych z perspektywy dobierania odpowiedniej strategii przez tłumacza - odnosi się przy tym do modelu pragmatycznego tworzenia terminów prawnych i tarczy dyskursu D. Kierzkowskiej (2002). Porusza przy tym kwestię zapewniania ekwiwalentów pod względem odbiorcy dalekiego i bliskiego oraz zorientowania tłumaczenia na kulturę źródłową bądź docelową. W artykule przywoływane są także przykłady ekwiwalentów proponowanych przez słowniki oraz innych tłumaczy dla różnych terminów pochodzących z tekstów prawnych. Artykuł przedstawia potencjalne problemy tłumacza tekstów prawnych i zawiera sugestie co do najsłuszniejszych - w ocenie autorki - rozwiązań. Tekst ma charakter w dużej mierze informacyjny, może zatem stanowić inspirację dla tłumacza chcącego zająć się przekładem tekstów prawnych, a także wyczulić go na możliwe pułapki, które może napotkać w procesie takiego typu tłumaczenia.

Artykuł drugi w rozdziale dotyczącym tłumaczeń specjalistycznych napisany został przez Joannę Grzybek i nosi tytuł „Pragmatyczne i kulturowe aspekty oceny tłumaczenia dokumentów z zakresu prawa cywilnego". Językami przedmiotowymi artykułu były język chiński, niemiecki i polski. Na wstępie autorka zwraca uwagę na pragmatyczny i kulturowy aspekt tłumaczenia języka prawa; podkreśla jak istotny jest wpływ kultury prawnej na prawo, jak i jego język w obrębie danego systemu prawnego i zaznacza, że brak znajomości kultury prawnej języka źródłowego i docelowego może doprowadzić do znaczących pomyłek. W drugiej części artykułu autorka skupia się już na poszczególnych rodzajach błędów popełnianych przez - zwłaszcza początkujących - tłumaczy. Część ta składa się siedmiu fragmentów poświęconych: błędom wynikającym z polisemii (charakterystycznych zwłaszcza $\mathrm{w}$ przypadku tłumaczenia $\mathrm{z}$ języka chińskiego), nieprawidłowemu zorientowaniu tłumaczenia, kwestii bezekwiwalentności, błędom stylistycznym i syntagmatycznym, tzw. fałszywym przyjaciołom oraz możliwej synonimii. Opisując rodzaje błędów autorka przedstawia konkretne przykłady ich występowania, a także sugeruje odpowiednie rozwiązania dla przytaczanych problemów. Artykuł może stanowić pomoc dla tłumaczy podejmujących się tłumaczenia prawniczego zwracając ich uwage na obszary szczególnie podatne na popełnianie błędów i stanowiąc jednocześnie zbiór wskazówek, jak tych błędów uniknąć.

Kolejny artykuł, „Ocena jakości tłumaczenia kandydata na tłumacza przysięgłego", napisany został przez dwie autorki: Danutę Kierzkowską i 
Zofię Rybińską. Artykuł na wstępie opisuje instytucję tłumacza przysięgłego $\mathrm{z}$ perspektywy prawa międzynarodowego i polskiego oraz w zwięzły sposób przedstawia jej rozwój $\mathrm{w}$ aspekcie historycznym. W zasadniczej części natomiast tekst dotyczy współczesnej regulacji oraz wymogów koniecznych do spełnienia w celu uzyskania statusu tłumacza przysięgłego w Polsce. Autorki przedstawiwszy zasady egzaminu na tłumacza przysięgłego prezentują poszczególne elementy oceny kandydata na podstawie tłumaczenia pisemnego i ustnego. Przytaczają także wymogi stawiane tłumaczom przysięgłym przez „Kodeks tłumacza przysięgłego” (2005). Artykuł kończy podsumowanie egzaminów na tłumacza przysięgłego pod względem oceny prac egzaminacyjnych i popełnianych przez kandydatów błędów. Może on być cenną wskazówką dla osób ubiegających się o status tłumacza przysięgłego, wskazując im najbardziej podatne na błędy obszary oraz kryteria, względem których dokonywana jest ocena kandydatów.

Artykuł kolejny odchodzi od tłumaczeń związanych z prawem, skupia się bowiem na tematyce przekładu audiowizualnego. Paweł D. Madej w artykule „Tłumaczenie napisów filmowych i jego weryfikacja” zwraca uwagę na kwestię badania jakości napisów filmowych. Autor opisuje proces powstawania napisów filmowych, a następnie zwraca uwagę na ograniczenia, którym podlega tłumacz: techniczne, językowe oraz kulturowe. Analizując każdy rodzaj ograniczeń podaje odpowiednie przykłady ich występowania. Następnie przechodzi do przedstawienia tytułowego problemu weryfikacji napisów filmowych. Odnosi się przy tym do etapów weryfikacji wg B. Kielar (analizę tekstu, sprawdzanie przekładu i ocenę przekładu). Przedstawia również badania przeprowadzone w postaci ankiety wśród kinomanów (osób o wyższym wykształceniu anglistycznym, innym wykształceniu wyższym oraz bez wykształcenia wyższego) dotyczące weryfikacji napisów filmowych. Zaprezentowane wyniki badań sugerują, że napisy są dobrze odbierane przez widzów, jednak potrzeba weryfikacji napisów filmowych spostrzegana jest głównie przez osoby związane $\mathrm{z}$ tłumaczeniami, mające świadomość możliwych do popełnienia błędów. Artykuł w zwięzły sposób charakteryzuje kwestię jakości tłumaczeń audiowizualnych i może stanowić źródło informacji dla osób chcących zajmować się tego typu tłumaczeniami.

Artykuł "Cultural and Pragmatic Aspects of Translating National Geographic Articles" autorstwa Marty Pikor-Niedziałek to studium przypadku oparte na analizy tłumaczeń artykułów z czasopisma National Geographic zamieszczanych w jego polskim odpowiedniku - National Geographic Polska. Autorka przedstawia wyniki przeprowadzonych badań, wskazując najczęstsze dokonywane przez tłumaczy zabiegi: wprowadzenie dodatkowej informacji do tekstu docelowego lub usunięcie elementów pojawiających się w tekście źródłowym, zmiany w akapicie wprowadzającym do artykułu, przesunięcia zdań i akapitów, czy zmiany tytułów i podtytułów. Każdy z zabiegów obrazuje przy tym różnymi przykładami pochodzącymi z artykułów publikowanych w National Geographic Polska. W artykule wyróżnione także zostały techniki tłumaczeniowe wykorzystywane podczas tłumaczenia artykułów popularnonaukowych (m.in. zastosowanie 
hiperonimu bądź hiponimu lub zmiana stylu z literackiego na bardziej „naukowy”). Podsumowując artykuł autorka stara się uzasadnić zmiany wprowadzane przez tłumaczy wskazując na aspekty kulturowe i pragmatyczne. Tekst zwraca uwagę czytelnika na problematykę tłumaczeń artykułów popularnonaukowych, które - choć de facto specjalistyczne plasują się na pograniczu tłumaczenia specjalistycznego i literackiego, stanowiąc pod pewnymi względami wyzwanie dla tłumacza.

Ostatnim artykułem rozdziału drugiego jest napisany przez Barry'ego Keane'a tekst pod tytułem: „On Translating Anna Stanisławska's Transakcja, albo opisanie całego życia jednej sieroty, przez żałosne treny od tejże samej pisane roku 1685 (A Transaction, or a Description of the Entire Life of One Orphan Girl through Doleful Laments Written by the Same 1685)". W artykule autor przedstawia dokonane przez siebie tłumaczenie utworu Anny Stanisławskiej. Zapoznaje czytelnika z historią poetki, wskazując jednocześnie na pewne trudności wynikające $\mathrm{z}$ tłumaczenia staropolskiej poezji na język angielski, ilustrując tekst licznymi fragmentami oryginału i tlumaczenia. Autor podsumowuje tekst streszczeniem pozostałej części życia Anny Stanisławskiej i wyraża nadzieję, że dzięki temu tłumaczeniu historia ta ma szansę trafić do znacznie szerszego grona odbiorców. Artykuł zachęca czytelnika do zapoznania się z całością tłumaczenia utworu, a także, co dla tłumacza może być szczególnie ciekawe, do porównania tłumaczenia z tekstem źródłowym.

Na rozdział trzeci - jak już wspomniano - składa się tylko jeden artykuł: „Klasyfikacja błędów tłumaczeniowych - teoria i praktyka”, którego autorem jest Krzysztof Hejwowski. Tekst porusza problem błędów popełnianych w tłumaczeniach przez studentów studiów językoznawczych. Autor opisuje najczęściej popełniane błędy i klasyfikuje je w czterech głównych kategoriach: błędy tłumaczenia syntagmatycznego (np. tzw. fałszywi przyjaciele lub kalki), błędy mylnej interpretacji (m.in. pomylenie dwóch różnych syntagm lub mylne odczytanie modalności tekstu), błędy realizacji (takie jak „podttumaczenie” lub błędy języka docelowego) i wreszcie błędy metatranslacyjne (opuszczenia i dodatki, dobór techniki tłumaczeniowej, pozostawianie dwóch wersji tłumaczenia itp.). Każdy rodzaj błędu został krótko scharakteryzowany, niektóre zaś zobrazowane zostały przykładami z tłumaczeń studentów. W podsumowaniu autor przedstawia opracowaną przez siebie klasyfikację błędów na rzecz oceniania prac studentów (wraz ze stosowanymi przez siebie skrótami) oraz wskazuje na trudność oceny tłumaczenia zwłaszcza $w$ ramach pracy dydaktycznej - z uwagi na fakt, że błąd nie zawsze jest równy innemu błędowi, co czyni taką ocenę silnie subiektywną. Artykuł może stanowić pomoc dla osób zajmujących się nauczaniem tłumaczenia, wskazując im pewne ramy, w których możliwe jest pewne dokonanie oceny; a także dla samych studentów, przestrzegając ich przed popełnianiem tych najczęściej spotykanych błędów.

Pozostawiając kwestie merytoryczne warto także krótko skomentować warstwę redakcyjną książki. Publikacja wydana została w poręcznym formacie; czcionka ma klasyczny, wygodny w czytaniu krój. Tytuły i 
śródtytuły zapisane są kapitalikami, co zdecydowanie ułatwia orientację w tekście. Artykuły, w tym i spisy bibliograficzne, sformatowane są jednolicie. Nieliczne literówki (dostrzeżone - zaledwie trzy) nie przeszkadzają w odbiorze tekstu. Różnicę stanowi jedynie sposób przedstawiania przykładów (tabele, wytłuszczanie terminów, wypunktowanie), co wynika jednak z faktu, że artykuły mają różny charakter i ujednolicenie tej kwestii mogłoby stanowić pewną trudność.

„Jakość i ocena tłumaczenia” jest publikacją w zdecydowanie przekrojowy sposób przedstawiającą problem zawarty w jej tytule. $\mathrm{Na}$ przykładzie przedstawionych artykułów widać, że mogą stanowić one cenną pomoc zarówno dla tłumaczy, jak i osób kształcących się w tym kierunku. 
Konrad Juszczyk: Szablon dla autorów Investigationes Linguisticae

\section{Bibliografia}

Kopczyński A., Kizeweter M. (Ed.)2009. Jakość i ocena tłumaczenia. Warszawa: Wydawnictwo SWPS „Academica”. 